\title{
Challenges in the Attainment of Qualitative University Education in Nigeria: A Case Study on Nnamdi Azikiwe University, Awka
}

\section{Faith Ogechukwu Okoye ${ }^{1}$ Anachuna, Obinna Nonso ${ }^{2 \rtimes(D)}$}

1,2Department of Educational Management and Policy, Faculty of Education,Nnamdi Azikiwe University, Awka, Nigeria.

Email:fo.okoye@unizik.edu.ng.Tel:+2348033526923

'Email:on.anachuna@unizik.edu.ng.Tel:+2348063260029

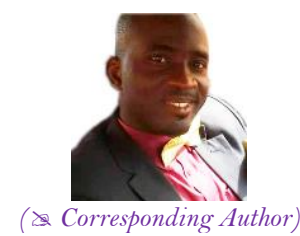

Corresponding Author

\begin{abstract}
The major thrust of tertiary education in Nigeria is for transformation and national development. The study was purposed to investigate the emerging problems bedevilling tertiary education such as excessive workload for lecturers, overcrowded student population and politicization of education. Three research questions guided the study while three hypotheses were tested at 0.05 level of significance. Out of 118 lecturers in the faculty of education, Nnamdi Azikiwe University, Awka, 50 was drawn randomly as the sample for the study. Three experts validated the instrument. A twenty item researchers' structured questionnaire was used for data collection and analysed using mean and z-test. The reliability of the instrument was determined using Cronbach Alpha method which yielded an index of 0.85 , this was considered adequate. Findings showed that excessive workload and overcrowded population demean lecturers and students output respectively and bring about falling standard in university education. Based on the findings, it was recommended among others that employment of additional qualified personnel is imminent. Also government should release more funds to tertiary institutions to cushion the effect of students over population.
\end{abstract}

Keywords: Education, Emerging problems, Tertiary education.

JEL Classification: I20, I29 and I23.

\section{Introduction}

In the whole universe, the only potent tool, process, lifelong phenomenon and long term enduring avenue for transformation and development of the society is education. Though education had been perceived diversely by various societies, yet its significance to human growth and development remain unquestionable. Education of human beings starts from birth to death. The holistic essence of education does not end with schooling. In effect, Okoye (2008) in his book, "Schooling without Education" presents systematic desiderata of what typifies education in Nigerian context. A plethora of detailed definition of education by various scholars span through history. However, Oladosu (2010) summarized these definitions as to have three basic points in common: that, "education is a process, that it has a content and that it has a method". In fact, education can be seemingly captured as the total process of human learning by knowledge is imparted, faculties trained and skills developed (Farrant, 1981). Furthermore, highlighting the necessity of education, Osokoya (2003) poignantly portrayed education as 'light' and 'life'. By implication, any society devoid of the rays of light beamed on its citizens by education is bound to go to extinct. In addition, education is a development which needs to have a sound beginning if it is to be healthy and protective. Being a developmental process that one undergoes all through one's life, Okoye (2014) notes that the outcome of education is dependent on how an individual's potentiality is tailored. Thus a formidable beginning begets a sound structure geared towards national development. The reverse invariably leads to primitivism.

More so, the educative processes encompass the non-formal, informal and formal structures. At this juncture, one can further describe education in the views of Obanya (2009) who perceived the holistic and comprehensive nature of education from horizontal and vertical dimensions in Figure 1.

An overview of the definitions so far portrays the import of education and the need to evaluate and re-evaluate the emerging problems in university education. Hence, Okoye (2008) underscores that, failure to educate the citizens properly ipso facto implies opting for the institutionalization of ignorance and, thereby, a systematic pauperization of human capital. Consequently, he posits that the distortion and misdirection of education implies, in reality, a negation of the process of developing the best of individuals for the collective well-being of society.

Considering the indispensability of education, university education amongst constituents of tertiary education in Nigeria is the third tier of education that gives diffusion of knowledge to Nigerian youths after secondary education. 


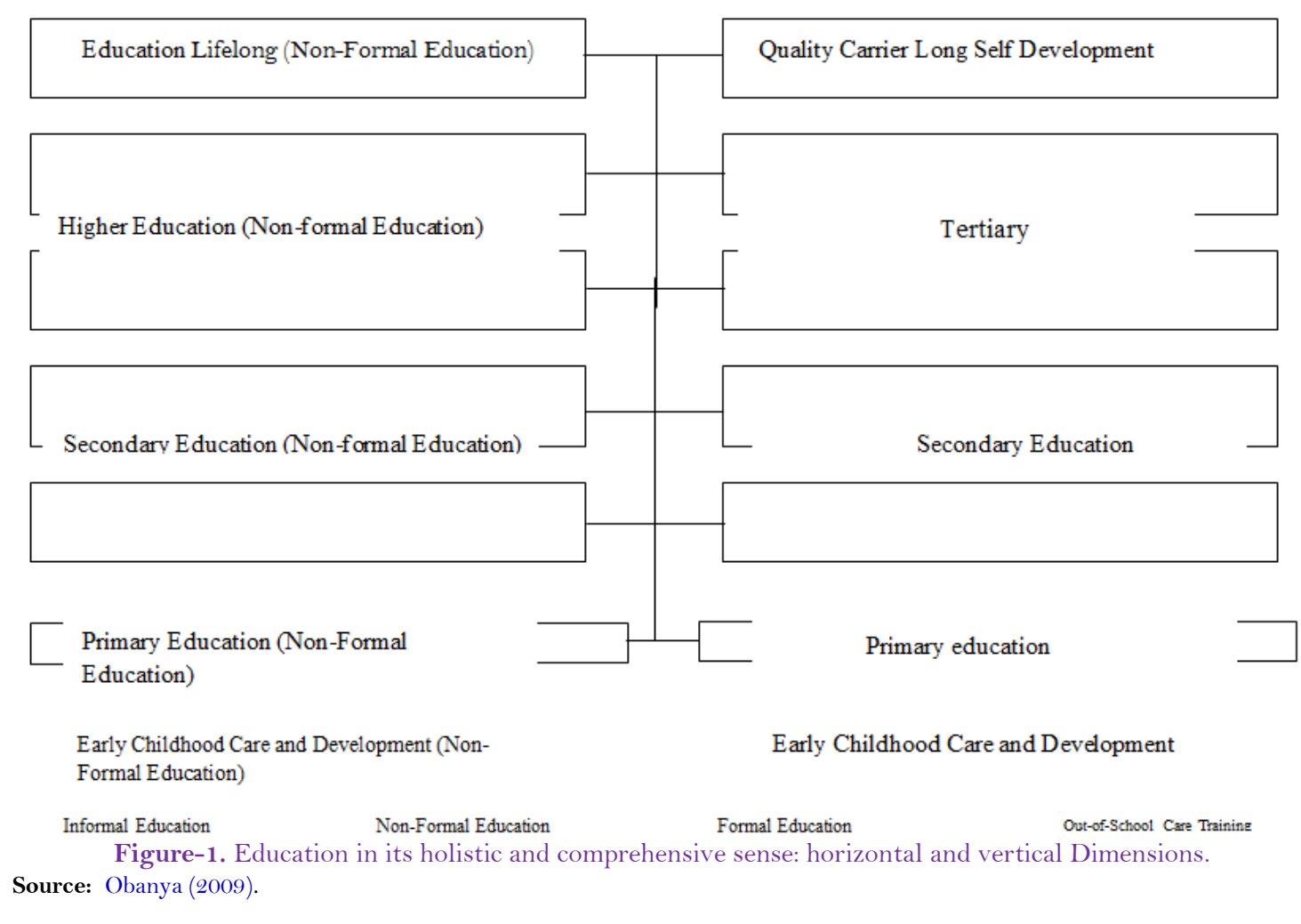

The Federal Republic of Nigeria (2004) National Policy on Education, Sec 64 stipulates that, University education shall make optimum contribution to national development by:

a) Intensifying and diversifying its programmes for the development of high level manpower within the context of the needs of the nation.

b) Making professional course contents to reflect our national requirements.

c) Making all students, as part of a general programme of all round improvement in university education, to offer general study courses such as history of ideas, philosophy of knowledge and nationalism.

In view of the foregoing virtually all parents desire and spend their last kobo to enrol their wards into the university. This is solely on the grounds that acquisition of certificate is considered a determinant factor for credible employment. Hence, Okoye (2008) asserts that, "certificates are regarded as meal tickets," one's field of study notwithstanding. As a result of massive Nigerian graduates unemployment, lucrativeness determines choice of job not field of learning in Nigeria. Hitherto comes up the big question, whether the desperate striving for university degrees/ certificates has evidenced in human capital development. Disheartenly, Okoye (2008) opined that universities in Nigeria have in their student population, individuals who do not possess the intellectual requirements for university education. Thus, certificate bearers who are not truly educated cannot cope with the task and challenges of sustainable development. In view of the foregoing, negating university carrying capacity by the influx of undergraduates into Nigerian universities has many implications. The table below presents the scenario from 2010-2013 as follows:

Table-1. Number of Applicants Seeking Admission into Nigeria Universities and the carrying capacities

\begin{tabular}{c|c|c|c|c}
\hline Year & University & Applicants & Carrying Capacity & \% Of Carrying Capacity \\
\hline $2010 / 11$ & 112 & $1,493,611$ & 450,000 & 30.13 \\
\hline $2011 / 12$ & 117 & $1,503,933$ & 500,000 & 33.25 \\
\hline $2012 / 13$ & 128 & $1,735,729$ & 520,000 & 29.96 \\
\hline
\end{tabular}

A cursory look at Table 1 shows geometrical progression of applicants cum the yearly carrying capacity provided by National University Commission (NUC). By implication, the imbalance would result to multifaceted lapses on the part of the lecturers and government to achieve the objectives of university education. This is seriously an emerging problem challenging university education in Nigeria. The percentage ratio of the 2012/13 carrying capacity is far below the preceding year. This portends that the wider the yawning gap between applicants and carrying capacity provided, the more devastating effect on university education. Concurring with the view point, Communiqué issued by Committee of Vice Chancellors of Nigerian Universities Communique (2012) remarks that, 'although the number of universities in Nigeria has increased, this rapid growth has not necessarily led to a realization of the objectives for which the institutions were set". Consequently, the researchers are not oblivious of the teething problems in the university system in Nigeria such as inadequate funding, infrastructures, unqualified manpower, outdated academic equipment, decreasing quality, limited access, increasing cost of education materials/school fees. However, in the context of this research, the focus would be on the emerging problems which border on excessive workload for university lecturers, overcrowded student population and politicization of university education in Nigeria. The scope will be delimited to lecturers in Nnamdi Azikiwe University, Awka. Against this backdrop, the study examined the emerging problems in Nigeria university education. The need to investigate the emerging problems and proffer suggestions on how to correct the imbalance spurred the conduct of the research.

\subsection{Statement of the Problem}

University education in Nigeria is fraught with numerous problems which cut across academic, socio-economic, political, ethnic and so on. However, the problem is how to relate the outcome of the university with the needs of 
the society, bearing in mind the emerging problems rearing up ugly head in university education. Neglecting this aspect would dastardly affect the frantic efforts to achieve the philosophy of Nigerian education as enshrined in the Federal Republic of Nigeria (2004). Education in Nigerian university inadvertently received influx of undergraduates/entrants in the past decade. The overcrowded student population in Nigerian university affect the learning outcomes drastically. Some students roam about the university environment without attending lectures. Others who attend may stand for the rest of lecture period, seat on bare floor writing their exams, write one course in shifts which is susceptible to leakage of questions, attend faculty wide lectures without public address system for effective communication, experience three to four different lectures going on simultaneously in one lecture hall. At times some students over stay the stipulated number of years apportioned for the programmes they were enrolled for. The imbalances of staff/student ratio have further exacerbated the situation, as well as proliferation of academic programmes. In recent years, the conspicuous nature of imbalance presented by the carrying capacity provided by the National University Commission (NUC) for Nigerian universities had been thwarted. The increasing university enrolment negate the carrying capacity of the institution, thus obliterate the frantic efforts of qualitative education. An overview the current number of universities cum students enrolment simply shows unimaginable overpopulation.

There is no doubting fact that factors that inhibit optimal performance of university lecturers must be eliminated. Lucidly, any university that fails to provide qualitative education for her undergraduates invariably supervises its own liquidation. This leads to the issue of excessive workload for university lecturers. Despite the 'publish' or 'perish' syndrome paraded as determinant factor for lectures enhancement, some lecturers work round the clock in order to cover learning activities encompassing Regular academic programme, self-sustaining programmes like Continuous Education Programme (CEP), Sandwich, and in some cases Diploma programme within the academic session. There is no break in the academic chain of the three programmes thereby subjecting lecturers to uncomfortable condition of service and avoidable stress/strain devoid of vacation or break all through the year. To ones dismay, politicization of university education is a serious bug eating up the fabrics of learning outcome in Nigerian universities. The proliferation of universities by philanthropists and some religious denominations without recourse to the NUC benchmark is a major problem to university education. Sequel to ineptitude leadership and poor standards, unbecoming activities such as sorting, e-cheating, exorbitant charges for consultancy, accreditation manoeuvre' flouting the quality assurance benchmark of the National Universities Commission (NUC), examination racketeering, man know man during admission and promotions are platforms yearning for university reforms. These unwholesome practices lower the standard of university education in Nigeria and the collapse of some institutions mid-way. This in essence spurred the research.

\subsection{Research Questions}

The following research questions guided the study:

1. What challenges do excessive workload of university lecturers have in attainment of qualitative education?

2. How does overcrowded student population hinder university learning outcomes?

3. What are the related problems associated with politicization of university education.

\subsection{Hypotheses}

The following hypotheses were tested at 0.05 level of significance:

1. There is no significant difference in the mean response ratings of male and female lecturers on the challenges of excessive workload on university lecturers in the attainment of qualitative education.

2. There is no significant difference in the mean response ratings of male and female lecturers on how overcrowded students' population hinders university learning outcomes.

3. There is no significant difference in the mean response ratings of male and female lecturers on the related problems associated with politicization of university education.

\section{Method}

Descriptive survey design was adopted for the research. The population of the study comprised all the 118 lecturers in the Faculty of Education, Nnamdi Azikiwe University, Awka. The sample for the study was 50. The instrument for data collection was a 20 item questionnaire. The instrument was validated by three experts, one in Measurement and Evaluation and two in Educational Management and Policy, Nnamdi Azikiwe University, Awka. The reliability of the instrument was determined using Cronbach Alpha method and the value was 0.85, this was considered adequate. The data collected were analysed with mean and z-test. Any item with a mean score of 2.50 and above is considered as being positive and accepted whereas any mean score less than 2.50 is negative and unacceptable.

\section{Results}

\subsection{Research Question 1}

What challenges do excessive workload of University lecturers have in attainment of qualitative education?

Table 2 indicates that all the items ( 1 to 9) except item 5 had mean scores above the cutoff point of 2.50 . Furthermore, the table revealed that the grand mean is 3.14 and it is equally above the benchmark of 2.50 , thus depicting that the respondents agreed that excessive workload of university lecturers pose lots of challenges in the attainment of qualitative university education.

\subsection{Research Question 2}

How does overcrowded student population hinder university learning outcomes? 
Table-2. Descriptives of the Respondents' Responses in Relation to Challenges Excessive Workload of University Lectures have in Attainment of Qualitative Education

\begin{tabular}{|c|c|c|c|c|c|c|c|}
\hline \multirow[t]{2}{*}{$\mathbf{S} / \mathbf{N}$} & \multirow{2}{*}{$\begin{array}{l}\text { Lecturers workload in } \\
\text { university are over-stretched } \\
\text { within the academic session } \\
\text { through: }\end{array}$} & \multicolumn{2}{|c|}{$\begin{array}{l}\text { Male lecturers } \\
\qquad(\mathrm{N}=18)\end{array}$} & \multicolumn{2}{|c|}{$\begin{array}{l}\text { Female lecturers } \\
\qquad(\mathrm{N}=32)\end{array}$} & \multirow{2}{*}{$\begin{array}{c}\text { Total } \\
\\
\bar{x}\end{array}$} & \multirow[t]{2}{*}{ Decision } \\
\hline & & $\bar{x}$ & Remks & $\bar{x}$ & Remks & & \\
\hline 1 & $\begin{array}{l}\text { Undergraduates regular academic } \\
\text { programmes }\end{array}$ & 2.66 & Agree & 3.04 & Agree & 2.85 & Agree \\
\hline 2 & Continued Education Programmes & 3.09 & Agree & 3.50 & Agree & 3.26 & Agree \\
\hline 3 & Sandwich programmes & 2.54 & Agree & 3.03 & Agree & 2.78 & Agree \\
\hline 4 & $\begin{array}{l}\text { Computation of results for nos } 1-3 \\
\text { above }\end{array}$ & 3.08 & Agree & 3.50 & Agree & 3.29 & Agree \\
\hline 5 & $\begin{array}{l}\text { Administrative functions for } \\
\text { various program } \\
\text { mes }\end{array}$ & 2.05 & disagree & 1.08 & disagree & 1.56 & Disagree \\
\hline 6 & Teaching nos $1-3$ above & 3.50 & Agree & 3.55 & Agree & 3.52 & Agree \\
\hline 7 & $\begin{array}{l}\text { Marking of scripts for nos } 1-3 \\
\text { above }\end{array}$ & 3.70 & Agree & 3.88 & Agree & 3.79 & Agree \\
\hline 8 & $\begin{array}{l}\text { Administration of continuous } \\
\text { assessment test for nos } 1-3 \text { above }\end{array}$ & 3.70 & Agree & 3.88 & Agree & 3.79 & Agree \\
\hline 9 & Invigilation of exams for nos $1-3$ & 3.00 & Agree & 3.88 & Agree & 3.44 & Agree \\
\hline & Total Grand mean & 3.03 & Agree & 3.26 & Agree & 3.14 & Agree \\
\hline
\end{tabular}

Table-3. Descriptives of the Respondents' Responses in Relation to How overcrowded Student Population Hinder Learning Outcomes

\begin{tabular}{|c|c|c|c|c|c|c|c|}
\hline \multirow[t]{2}{*}{$\mathbf{S} / \mathbf{N}$} & \multirow[t]{2}{*}{ 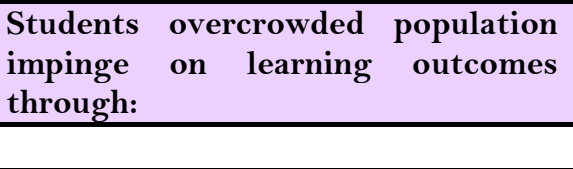 } & \multicolumn{2}{|c|}{$\begin{array}{l}\text { Male lecturers } \\
\qquad(\mathrm{N}=18)\end{array}$} & \multicolumn{2}{|c|}{$\begin{array}{l}\text { Female lecturers } \\
\qquad(\mathrm{N}=32)\end{array}$} & \multirow{2}{*}{$\begin{array}{c}\text { Total } \\
\bar{x}\end{array}$} & \multirow[t]{2}{*}{ Decision } \\
\hline & & $\bar{x}$ & Remks & $\bar{x}$ & Remks & & \\
\hline 10 & $\begin{array}{l}\text { Students standing all through the } \\
\text { lecture period }\end{array}$ & 2.51 & Agree & 2.58 & Agree & 2.54 & Agree \\
\hline 11 & $\begin{array}{l}\text { Some students writing exams on bare } \\
\text { floor }\end{array}$ & 2.50 & Agree & 2.60 & Agree & 2.55 & Agree \\
\hline 12 & $\begin{array}{l}\text { Students sitting five or six on a bench } \\
\text { for exams }\end{array}$ & 3.00 & Agree & 3.60 & Agree & 3.30 & Agree \\
\hline 13 & $\begin{array}{l}\text { Epileptic power supply and poor } \\
\text { ventilation of exam halls }\end{array}$ & 3.00 & Agree & 3.60 & Agree & 3.30 & Agree \\
\hline 14 & Inadequate lecture/exam halls & 2.57 & Agree & 3.00 & Agree & 2.78 & Agree \\
\hline 15. & $\begin{array}{l}\text { Inadequate attendance to lectures } \\
\text { ( } 75 \% \text { minimum attendance) }\end{array}$ & 3.87 & Agree & 3.40 & Agree & 3.63 & Agree \\
\hline 16 & Examination malpractice & 3.09 & Agree & 3.50 & Agree & 3.29 & Agree \\
\hline \multirow[t]{2}{*}{17} & $\begin{array}{l}\text { Erosion of standards in tertiary } \\
\text { education }\end{array}$ & 3.08 & Agree & 3.58 & Agree & 3.33 & Agree \\
\hline & Total/Grand mean & 2.95 & Agree & 3.23 & Agree & 3.09 & Agree \\
\hline
\end{tabular}

Table 3 above indicates that all the items (10 to 17) had mean scores above the cutoff point of 2.50 . Furthermore, the table revealed that the grand mean is 3.09 and it is equally above the benchmark of 2.50 , thus depicting that overcrowded student population hinder university learning outcomes

\subsection{Research Question 3}

What are the related problems associated with politicization of university education?

Table-4. Descriptive of the Respondents' Responses in Relation to the Related Problems Associated with Politicization of University Education

\begin{tabular}{|c|c|c|c|c|c|c|c|}
\hline \multirow[t]{2}{*}{$\mathbf{S} / \mathbf{N}$} & \multirow{2}{*}{$\begin{array}{l}\text { University } \\
\text { Nigeria } \\
\text { through: }\end{array}$ is $\begin{array}{l}\text { politicized } \\
\end{array}$} & \multicolumn{2}{|c|}{$\begin{array}{l}\text { Male lecturers } \\
\qquad(\mathrm{N}=18)\end{array}$} & \multicolumn{2}{|c|}{$\begin{array}{l}\text { Female lecturers } \\
\qquad(\mathrm{N}=32)\end{array}$} & \multirow{2}{*}{$\begin{array}{c}\text { Total } \\
\bar{x}\end{array}$} & \multirow[t]{2}{*}{ Decision } \\
\hline & & $\bar{x}$ & Remks & $\bar{x}$ & Remks & & \\
\hline 18 & $\begin{array}{l}\text { Opening and running of many } \\
\text { educational institutions }\end{array}$ & 2.70 & Agree & 3.00 & Agree & 2.85 & Agree \\
\hline 19 & e-cheating & 2.76 & Agree & 2.70 & Agree & 2.73 & Agree \\
\hline \multirow[t]{2}{*}{20} & $\begin{array}{l}\text { Exorbitant prices } \\
\text { consultancy services }\end{array}$ & 3.00 & Agree & 2.56 & Agree & 2.78 & Agree \\
\hline & Total/Grand mean & 2.82 & Agree & 2.75 & & 2.78 & Agree \\
\hline
\end{tabular}

Table 4 indicates that all the items (18 to 20 ) had mean scores above the cutoff point of 2.50. Furthermore, the table revealed that the grand mean is 2.78 and it is equally above the benchmark of 2.50 , thus depicting that opening and running of many educational institutions, e-cheating and exorbitant prices for consultancy services are the related problems associated with politicization of university education in Nigeria.

\subsection{Test of Hypotheses}

Ho1 There is no significant difference in the mean response ratings of male and female lecturers on the challenges of excessive workload on university lecturers in attainment of qualitative education. 
Table-5. Table showing the z-test output of the ratings of male and female lecturers on the challenges of excessive workload on university lecturers in attainment of qualitative education.

\begin{tabular}{l|c|c|c|c|c|c|c}
\hline Variable & Gender & N & Mean & SD & z-cal & df & Decision \\
\hline $\begin{array}{l}\text { Excessive workload of } \\
\text { university lecturers }\end{array}$ & Male & 18 & 3.03 & 0.43745 & 1.83 & 48 & Not Significant \\
\cline { 2 - 8 } & Female & 32 & 3.26 & 0.45249 & & & \\
\hline
\end{tabular}

Note: $z-c a l<1.96$ at 0.05 alpha level.

Result from Table 5 shows that the calculated t-value (1.83) is less than the critical t-value (1.96) at 0.05 level of significance; therefore the null hypothesis is upheld. Thus, it is concluded that there is no significant difference in the mean response ratings of male and female lecturers on the challenges of excessive workload on university lecturers in attainment of qualitative education.

Ho2 There is no significant difference in the mean response ratings of male and female lecturers on how overcrowded students population hinder university learning outcomes.

Table-6. Showing the z-test output of the ratings of male and female lecturers on how overcrowded students' population hinder university learning outcome

\begin{tabular}{l|c|c|c|c|c|c|c}
\hline Variable & Gender & N & Mean & SD & z-cal & df & Decision \\
\hline \multirow{2}{*}{$\begin{array}{l}\text { Overcrowded } \\
\text { students' population }\end{array}$} & Male & 18 & 2.95 & 0.42845 & 1.93 & 48 & Not Significant \\
\cline { 2 - 8 } \\
\cline { 2 - 8 } Note: z-cal< 1.96 at 0.05 alpha level.
\end{tabular}

Result from Table 6 shows that the calculated t-value (1.93) is less than the critical t-value (1.96) at 0.05 level of significance; therefore the null hypothesis is upheld. Thus, it is concluded that there is no significant difference in the mean response ratings of male and female lecturers on how overcrowded students population hinder university learning outcomes.

Ho3 There is no significant difference in the mean response ratings of male and female lecturers on the related problems associated with politicization of university education.

Table-7. Showing the z-test output of the ratings of male and female lecturers on the related problems associated with politicization of university education.

\begin{tabular}{l|l|l|l|l|l|l|l}
\hline Variable & Gender & $\mathbf{N}$ & Mean & SD & z-cal & df & Decision \\
\hline Politicization of University education & Male & 18 & 2.82 & 0.41945 & 1.68 & 48 & Not Significant \\
\cline { 2 - 8 } & Female & 32 & 2.75 & 0.40749 & & & \\
\hline Note: $z$-cal< 1.96 at 0.05 alpha level.
\end{tabular}

Note: $\mathrm{z}-\mathrm{cal}<1.96$ at 0.05 alpha level.

Result from Table 7 shows that the calculated t-value (1.68) is less than the critical t-value (1.96) at 0.05 level of significance; therefore, the null hypothesis is upheld. Thus, it is concluded that there is no significant difference in the mean response ratings of male and female lecturers on the related problems associated with politicization of university education.

\section{Discussion}

From the findings and analyses given in the above tables, it is evident that emerging problems in the area of excessive workload of university lecturers, students over crowded population and politicization of tertiary education pose serious challenges to the attainment of qualitative education and deface the main purpose of education in Nigeria. Regrettable, these factors impinge on the main purpose of university education.

When the main purpose of education is not met as a result of some overriding factors, one may be disturbed by the quality of products turned over to the society by the university. Categorically, no university efficiently deliver the desired educational objectives under overcrowded student population and unbearable workload on lecturers coupled with politicization of her education. Based on this platform, the university education in Nigeria needs overhauling he rebrand to products, meet the needs of her society and be able to face the global challenges of her time. Table one highlights different areas of excessive workload for university lecturers such as teaching of Regular student courses, Continuous education programmes, Sandwich, computation of results and marking of scripts for both regular and self-sustaining programmes of the university. From the analysis, it was found that the respondents strongly agreed that university lecturers are over-stretched while embarking on these academic exercises, all, within the same academic session without break or vacation. Was it not the English adage which says that, "all works and no play makes Jack a dull boy" this situation may result to inefficiency and ineffectiveness in discharging of duties by the lecturers. As such, and in the long run, half backed graduates are produced to the detriment of the society's growth and development. In recent years, the imbalance resulting from introducing selfsustaining programmes in the university without engaging commensurate manpower to teach the programmes has become a conspicuous problem. From one angle, it is a good avenue to cushion the effect of qualified candidates not given admission in the regular programmes of the university. But from the other angle, the debilitating effect could be envisioned by the views of Coombs (1974) who opined that, "a school system may be making relatively efficient and productive internal use of its resources in doing what it is now doing, but what it is now doing may not be especially relevant to the present and future needs of its society and of the individual students".

Table two shows that students over crowded population impinge on learning outcomes. The areas include: students standing throughout the lecture period which border of problems inadequate facilities, inadequate lecture/exam halls, students sitting more than the sitting capacity of a bench during examinations, writing on bare floor during examinations. Over population is an impending doom to every facet of life, educational sector notwithstanding. When students are subjected to unconducive learning environment, dearth of needed facilities, the society is bound to reap repercussions. The researchers are not oblivious of the fact that Nigeria is endowed with basic natural resources to substantially sustain influx of students in the university system. However, the crux of the matter hinges not on the total environment each academic session, instead the rate of the increase versus the 
rate of budgetary allocations provided by Nigerian government for education each year. The imbalance of economic provisions and the educational explosion varies. Years after the civil war in Nigeria emerge great increase and popular demand by stakeholders for university education because investment in university education pays off and therefore deserves government handsome support.

Data obtained from table three indicate that respondents strongly agreed that university education in Nigeria is politicized through opening and running of many educational institutions, e-cheating, exorbitant price for consultancy services. A glimpse of what transpires in some unapproved universities especially owned by individuals and religious organisations are uncalled for. In such establishments, standards are completely debased. The status quo for admission is "come as you are" etc. The outrageous amount of money charged by some lecturers for consultancy services tingles the ear. Worst still is the menace of e-cheating within the university system which supposedly is looked upon as citadel of learning. Hypothesis one states that there is no significant difference in the mean response ratings of male and female lecturers on challenges of excessive workload on university lecturers in attainment of qualitative education. The result in table four shows that the calculated t-value of 1.83 is less than the critical value of 1.96 at 48 degree of freedom and 0.05 level of significance. Since the calculated t-value is less than the critical value, null hypothesis is therefore retained. This implies that both male and female lecturers in the university experience the challenges of excessive workload.

Hypothesis two on Table 5 shows that both male and female lecturers opine that overcrowded student population hinder university learning outcome. The hypothesis was upheld implying that explosive population dastardly affect the desired effort of the government to provide qualitative education. At the long run, the university system may be opportunities for schooling without education. However, Oyebade (2005) remarks that, Nigeria is currently witnessing a period during which education and professional development at the university level are in increasing demand and the cost of providing this education has continued to rise astronomically, cost that the government cannot bear alone. Hypothesis three indicates that there is no significant difference in the mean response ratings of male and female lecturers on related problems associated with politicization of university education. This implies that irrespective of gender that university education is politicized. In essence, whether lecturers are males or females, their responses indicate that involvement in politicization cut across gender issue or barrier. Hence, the need for reformation of university policies and change of psyche among lecturers and students.

\section{Conclusion}

The study investigated emerging problems in Nigerian education. Findings from the research showed that university lecturers are over-stretched with excessive workload within an academic session, overcrowded student population impinge on learning outcomes and that university education is politicized in Nigeria the study noted that engaging more manpower to handle Self-sustaining programmes of the university will give lecturers lease of life to perform better. Government should endeavour to enhance budgetary allocation to university education, at least to UNESCO minimum stipulation of $26 \%$. The need for reformation of university policies and transformation of both lecturers and students psyche should be implemented.

\section{Recommendations}

Based on the findings of the study, the following recommendations were made:

Adequate funding of university education must be taken seriously by the three tiers of Nigerian government to cushion the effect of students' overpopulation.

1. Employment of more manpower to handle Self-Sustaining programmes of the university. This will improve the efficiency and effectiveness of lecturers.

2. National University Commission must brace up with adequate checks and balances for university education

\section{References}

Agbo, A. (2015). Varsities and carrying capacity. Retrieved from www.thenationonline.net.

Committee of Vice Chancellors of Nigerian Universities Communique. (2012). Darka: Trust Africa. Retrieved from www.trustafrica.org.

Coombs, P. (1974). Major problems facing educational planning of next decade. Unesco: International Institute for Educational Planning.

Farrant, J. S. (1981). Principles and practice of education. Lagos: Longman Group Limited.

Federal Republic of Nigeria. (2004). National policy on education. Lagos: NERDC Press.

Obanya, P. (2009). Dreaming, living and doing education. Ibadan: Educational Research and Study Group, University of Ibadan.

Okoye, I. C. (2008). Schooling without education: The Nigerian experience: Africana First Publishers.

Okoye, F. O. (2014). Education challenges for human development: The case of Anambra state. In E., O. Agbionu, U., J. Obidiegrwu and W. E. Adebola (Eds.), Adult literacy and non-formal education. Enugu: Good Success.

Oladosu, A., G. (2010). Arabic and Islamic education in Nigeria. In J., O. Abiri and A., A. Jekayinfa (Eds.), Perspective on the history of education in Nigeria. Lagos: Bamitex.

Osokoya, I. O. (2003). 6-3-3-4 education in Nigeria: History, strategies, issues and problems. Lagos: Laurel Educational Publishers.

Oyebade, S. A. (2005). Privatisation of university education in Nigeria: implications for educational management. In G., O. Akpa (Ed.), Deregulating the provision and management of education in Nigeria. Jos: NAEP.

Citation: Faith Ogechukwu Okoye; Anachuna, Obinna Nonso (2021). Challenges in the Attainment of Qualitative University Education in Nigeria: A Case Study on Nnamdi Azikiwe University, Awka. Asian Business Research Journal, 6: 1-6.

History:

Received: 4 February 2021

Revised: 8 March 2021

Accepted: 1 April 2021

Aublished: 22 April 202

Licensed: This work is licensed under a Creative Commons

Attribution 3.0 License (cc) E E

Publisher: Eastern Centre of Science and Education

Eastern Centre of Science and Education is not responsible or answerable for any loss, damage or liability, etc. caused in relation to/arising out of the use of the content. Any queries should be directed to the corresponding author of the article.
Acknowledgement: Both authors contributed equally to the conception and design of the study.

Funding: This study received no specific financial support.

Competing Interests: The authors declare that they have no competing interests.

Transparency: The authors confirm that the manuscript is an honest, accurate, and transparent account of the study was reported; that no vital features of the study have been omitted; and that any discrepancies from the features of the study have been omits

study as planned have been explained.
Ethical: This study follows all ethical practices during writing. 